Review

\title{
Genes and Dietary Fatty Acids in Regulation of Fatty Acid Composition of Plasma and Erythrocyte Membranes
}

\author{
Maria Lankinen ${ }^{1, * \mathbb{C}}$, Matti Uusitupa ${ }^{1}$ and Ursula Schwab ${ }^{1,2}$ \\ 1 Institute of Public Health and Clinical Nutrition, University of Eastern Finland, 70211 Kuopio, Finland; \\ matti.uusitupa@uef.fi (M.U.); ursula.schwab@uef.fi (U.S.) \\ 2 Department of Medicine, Endocrinology and Clinical Nutrition, Kuopio University Hospital, \\ 70210 Kuopio, Finland \\ * Correspondence: maria.lankinen@uef.fi; Tel.: +358-50-470-9365
}

Received: 15 October 2018; Accepted: 14 November 2018; Published: 16 November 2018

\begin{abstract}
The fatty acid compositions of plasma lipids and cell membranes of certain tissues are modified by dietary fatty acid composition. Furthermore, many other factors (age, sex, ethnicity, health status, genes, and gene $\times$ diet interactions) affect the fatty acid composition of cell membranes or plasma lipid compartments. Therefore, it is of great importance to understand the complexity of mechanisms that may modify fatty acid compositions of plasma or tissues. We carried out an extensive literature survey of gene $\times$ diet interaction in the regulation of fatty acid compositions. Most of the related studies have been observational studies, but there are also a few intervention trials that tend to confirm that true interactions exist. Most of the studies deal with the desaturase enzyme cluster (FADS1, FADS2) in chromosome 11 and elongase enzymes. We expect that new genetic variants are being found that are linked with the genetic regulation of plasma or tissue fatty acid composition. This information is of great help to understanding the contribution of dietary fatty acids and their endogenic metabolism to the development of some chronic diseases.
\end{abstract}

Keywords: fatty acid; diet; genotype; human; FADS

\section{Introduction}

Traditionally, the fatty acid compositions of plasma and its components (triglycerides (TG), phospholipids (PL), cholesteryl esters (CE)) have been used as biomarkers of dietary intake of certain fatty acids. Furthermore, the fatty acid compositions of adipose tissue and erythrocyte and platelet membranes reflect the dietary intakes of different fatty acids [1-4]. In particular, proportions of omega-3 long-chain unsaturated fatty acids in $\mathrm{CE}$ and in erythrocyte and platelet membranes reflect quite well the intakes of these fatty acids, e.g., from fatty fish. On the contrary, the major dietary saturated fatty acid, palmitic acid, is more problematic as a biomarker of saturated fatty acid intake due to its rapid desaturation and elongation to longer-chain fatty acids in the body and due to its endogenous de novo lipogenesis [5]. Still, based on long-term trial evidence, the palmitic acid content of CE also reflects dietary intake [4]. Odd-chain fatty acids (15:0 and 17:0) have been used as biomarkers for dairy fat intake, but they are also produced from gut-derived propionate [6] and exist in fish [7-9]. Moreover, the measured contents of given fatty acids in different biomarkers indicate only relative patterns of the fatty acids in the diet, and, e.g., incorporation of omega-3 polyunsaturated fatty acids (PUFAs) into various biomarkers may vary considerably $[10,11]$. Various fatty acid biomarkers reflect dietary intakes from a few days even to years, as does adipose tissue fatty acid composition [11]. Furthermore, well-known competition occurs between $n-6$ and $n-3$ PUFA; the higher the intakes and proportions 
of eicosapentaenoic acid (EPA) and docosahexaenoic acid (DHA) are, the lower the relative linoleic acid content of biomarkers [12,13]. Endogenous fatty acid metabolism is also quite complex, and some studies suggest, e.g., retroconversion of DHA to EPA and that DHA also interferes with linoleic acid metabolism [10]. Another example is that trans-fatty acid 18:1t incorporates markedly higher into TG and PL than CE and may result in a decreased conversion of linoleic acid to its more unsaturated metabolites [14]. Oleic acid (18:1n-9) is the dominant fatty acid in TGs, whereas linoleic acid (18:2n-6) is very abundant in CE fraction [15].

Postprandial fatty acid metabolism and fatty acid composition of biomarkers may be modified by other dietary components and factors related to glucose and insulin metabolism and cardio-metabolic health in general $[16,17]$. Finally, the fatty acid composition of various biomarkers is under genetic regulation $[18,19]$. Figure 1 summarizes the major factors affecting the fatty acid composition of serum lipids and cell membranes.

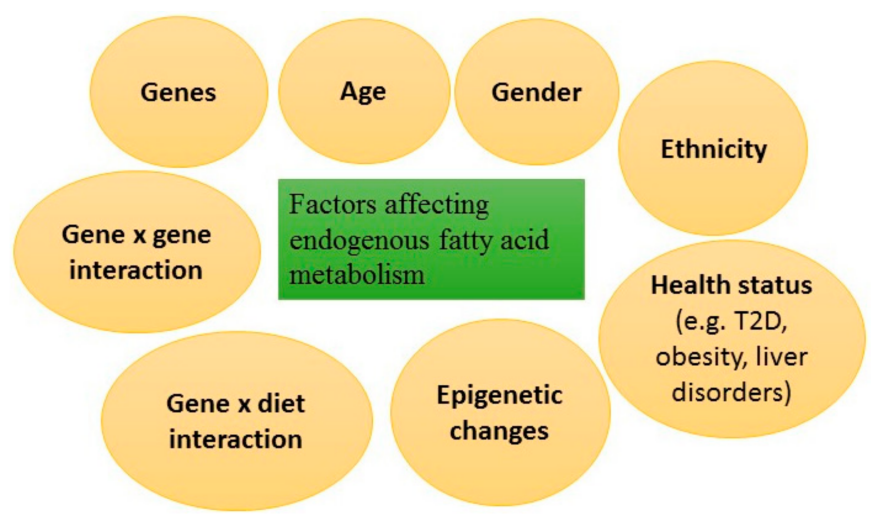

Figure 1. Factors affecting endogenous fatty acid metabolism. T2D, type 2 diabetes.

We became interested in the genetic regulation of fatty acid metabolism over 20 years ago when we examined whether polymorphism of the fatty acid binding protein 2 gene (FABP2) that is expressed in intestinal enterocytes modified postprandial lipemic response in humans [20]. In our oral fat-loading test, we examined postprandial triglyceride, chylomicron, and very-low-density lipoprotein TG in individuals homozygous for the Ala encoding allele (wild type) and individuals homozygous for the Thr54 allele variant. The Thr54 genetic variant was suggested to result in an increased absorption and processing of fatty acids in the intestine and showed an association with higher lipid oxidation and insulin resistance in Pima Indians [21] and with insulin resistance and increased intra-abdominal fat mass in Japanese men [22]. We found a markedly higher postprandial lipemic response in Finnish individuals homozygous for the Thr54 allele. Consequently, we also found an increased postprandial response of C14-C18 fatty acids in chylomicron and very-low-density lipoprotein (VLDL) TG in study persons homozygous for Thr54 variant [20]. However, we did not find any relative differences in the amounts of individual fatty acids introduced to these lipid fractions between these two genotype groups [23]. This particular genetic variant may also affect the postprandial TG content of high-density lipoprotein (HDL) in visceral obese individuals heterozygous for the Thr54 allele [24], and, interestingly, it may associate with reduced delta-6 desaturase (D6D) activity and lowered arachidonic acid (AA, 18:2n-6) content in obese children homozygous for Thr54 allele D [25]. In a clinical trial in patients with type 2 diabetes (T2D), individuals homozygous for the Thr54 allele showed an increased postprandial response of mono- and polyunsaturated fatty acids as an indication of increased fatty acid absorption [26]. In some other studies, postprandial lipemic response has not been related to this genetic polymorphism [16]. Nevertheless, these results on FABP2 genetic variation, along with rapidly increasing knowledge about genes involved in fatty acid desaturation and elongation, indicate that fatty acid absorption and metabolism are under tight genetic regulation, and there may occur gene-diet interaction in fatty acid metabolism [19]. 


\section{Methods}

We carried out a literature survey of genes and diet in the context of the regulation of fatty acid compositions in PubMed. We used the following search term: (genotype OR gene OR fads OR elovl) AND fatty acid AND (diet OR dietary intake OR nutrition) AND (plasma OR erythrocyte membrane) AND human NOT animal. The search was performed on 3 July 2018 and it gave 553 hits altogether. Relevant articles were selected based on their abstracts $(n=32)$.

\section{Genetic Variants of Fatty Acid Metabolism and Disease Risk}

Figure 2 illustrates how a given genetic variant of fatty acid metabolism could modify endogenous fatty acid metabolism, their downstream metabolites, and, finally, risk of diseases. Principally, genetic variation may increase or decrease the activity of certain steps in endogenous fatty acid metabolism, affecting either desaturation or elongation processes. This effect is also modified by other factors, as shown in Figure 1. Altogether, modified fatty acid metabolism can be demonstrated by examining the fatty acid content of plasma and its components, cell membranes, or adipose tissue. In most studies $[15,27,28]$, enzyme activities involved in fatty acid metabolism have been estimated by different ratios of certain fatty acids reflecting either desaturation or elongation of fatty acids to their longer chain metabolites (Figure 3 and Table 1). Furthermore, most of the known genetic variants (single-nucleotide polymorphisms, SNPs) associated with altered fatty acid metabolism are in fact genetic markers and their exact function is unknown. Even less is known about the interaction of genes and diet with regard to genetic regulation of endogenous fatty acid metabolism. In particular, genetic variants of the fatty acid desaturase (FADS) gene cluster in chromosome 11 (FADS1, FADS2) and elongases (e.g., ELOVL2 and ELOVL5) are involved in the regulation of fatty acid metabolism.

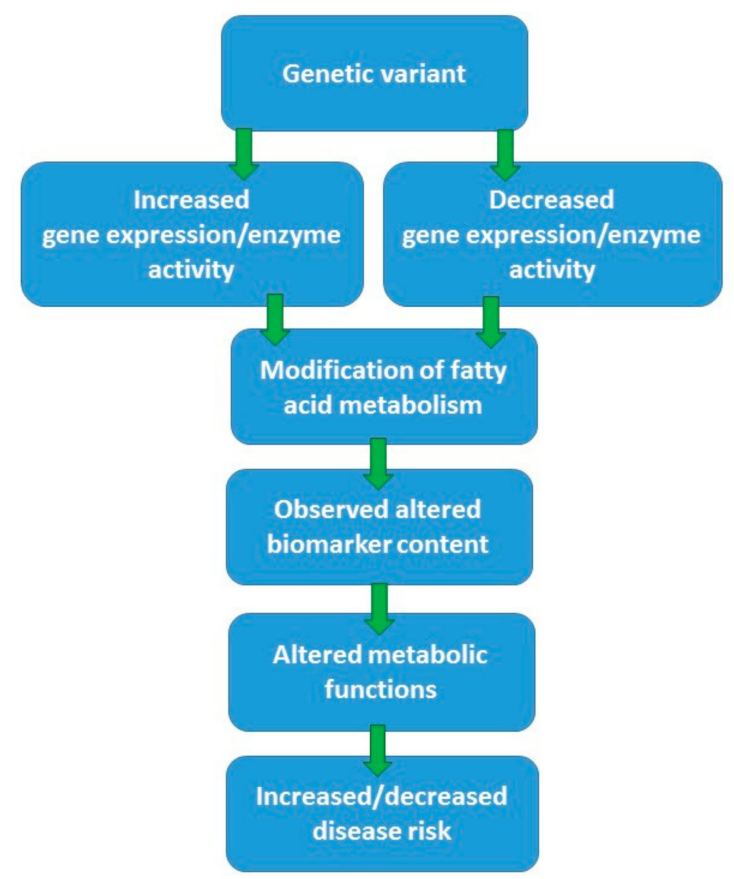

Figure 2. Impacts of genetic variants regulating fatty acid metabolism in the body.

Table 1. Fatty acid ratios used for the estimation of desaturase and elongase activities.

\begin{tabular}{cc}
\hline Estimated Desaturase/Elongase & Fatty Acid Ratio \\
\hline Stearoyl-CoA desaturase 1 (SCD1) & $16: 1 n-7 / 16: 0$ \\
Delta-6-delta (D6D) & $18: 3 n-6 / 18: 2 n-6$ \\
Delta-5-delta (D5D) & $20: 4 n-6 / 20: 3 n-6$ \\
Elongase & $18: 1 n-7 / 16: 1 n-7$ \\
\hline
\end{tabular}




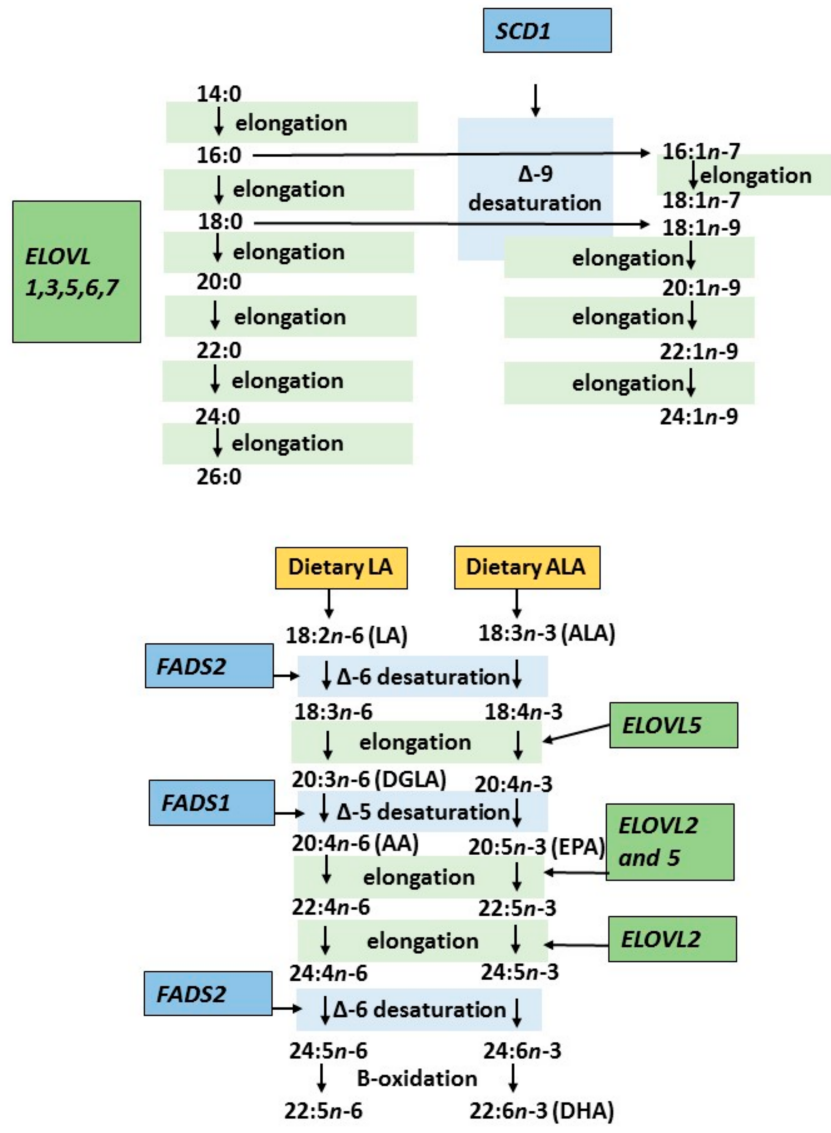

Figure 3. Simplified figure of the synthesis of fatty acids in the human body including key enzymes regulating fatty acid metabolism and genes coding them. AA, arachidonic acid; ALA, alpha-linolenic acid; DGLA, Di-homo-gamma linolenic acid; DHA docosahexaenoic acid; ELOVL, fatty acid elongase; EPA, eicosapentaenoic acid; FADS, fatty acid desaturase; LA, linoleic acid; SCD, stearoyl-CoA desaturase 1.

Many studies suggest that delta-5-desaturase (D5D) activity (FADS1) is associated with a lower risk of T2D [29], while stearoyl-CoA desaturase 1 (SCD1) [27] and delta-6-desaturase (D6D, FADS2) variants are linked with insulin resistance and worsening of glucose tolerance or an increased risk of T2D [15,29-32]. In the longitudinal Finnish Diabetes Prevention Study, we confirmed the preventive effect of D5D activity on future T2D risk, and we showed that a higher insulin sensitivity may explain this finding [33]. Furthermore, based on the Metabolic Syndrome in Men (METSIM) study population where erythrocyte membrane fatty acids were analyzed, high estimated elongase activity was associated with a beneficial effect on glucose tolerance [30]. In another study carried out with the METSIM study population where the fatty acid compositions of serum lipids from TG, CE, and PL were analyzed, D6D activity predicted a worsening of glycemia, whereas elongase activity had an opposite effect on glycemia [15]. Furthermore, it is not surprising that genetic markers of the FADS cluster are also associated with lipid metabolism, in particular with HDL and triglyceride metabolism [34], but the data on cardiovascular disease (CVD) risk are lacking. In a meta-analysis studying associations between omega-3 fatty acid biomarkers and coronary heart disease (CHD), there was no significant interaction identified by FADS variant for incident CHD events [35]. Interestingly, in a genome-wide association study (GWAS) of Greenland Inuits, ELOVL2 showed an association with sleep duration, age, and DNA methylation, and ELOVL5 coding mutations may lead to spinocerebellar ataxia; as an example of epigenetic effect, epigenetic markers were associated with depression and suicide risk [19]. Disease per se may also modify enzyme activities involved in endogenous fatty acid metabolism. For instance, non-alcoholic steatohepatitis was found to affect desaturase enzyme activities in the liver in a cross-sectional study [36]. 


\section{Genetic Regulation of Endogenous Fatty Acid Metabolism}

Figure 3 summarizes the key enzymes regulating fatty acid metabolism in the body. Recently, many new genetic variants have been identified that may modify endogenous fatty acid metabolism and, consequently, the profile of fatty acid composition in different plasma components or tissues. In particular, the knowledge of genes participating in elongation processes has increased rapidly. We expect that new genetic variants linked with biomarkers reflecting the fatty acid composition of plasma components or cell membranes will be identified in the future. Some of these novel genetic variants are listed and briefly discussed in Table $2 \mathrm{~A}-\mathrm{C}$ and the next chapter.

There has been huge progress in research into fatty acid metabolism over the last 20 years. Both single-nucleotide polymorphism studies and GWAS have focused on enzymes regulating endogenous fatty acid metabolism (Figure 3). Specifically, these enzymes regulate both desaturation and elongation processes in fatty acid metabolism. Their genetic variations are associated with altered accumulation of long-chain PUFAs in the cell membranes of tissues and plasma lipid components [19]. Epigenetic variation of these genes may also play a role in this context [37,38]. In the present review based on a literature survey and our own studies, we focus on studies investigating the genetic regulation of plasma and membrane fatty acids in relation to the putative interaction between dietary fat and fatty acid incorporation into different biomarkers used to evaluate the quality of dietary fat in observational and intervention studies.

Table 2 summarizes the current knowledge about the genetic variants that have been associated with endogenous fatty acid metabolism. Most of the studies deal with individual SNPs of the FADS cluster (Table 2B) or elongases, and only some of them are based on GWAS (Table 2A). Among them, only a couple studies are true intervention trials (Table 2C), most without a specific hypothesis, and others are observational trials.

A GWAS based on the Invecchiare in Chianti (InCHIANTI) study population and Genetics of Lipid Lowering Drugs and Diet Network (GOLDN) study population used for replication observed that the FADS genetic cluster located in chromosome 11 was associated with AA, eisosadienoic acid (EDA), and EPA, and the EVOLV2 genetic variant in chromosome 6 with EPA concentrations, but in the replication study, the association with EPA was not confirmed [18] (Table 2A). A few years earlier, two cross-sectional studies from Germany reported that haplotypes of the FADS1 and FADS2 region was associated with AA and many other longer-chain fatty acids of both the $n-6$ and $n-3$ series [39] (Table 2B); specifically, minor alleles of FADS1/FADS2 showed mostly an association with decreased levels of plasma phospholipids. In a later study [40], associations between FADS1/FADS2 haplotypes and fatty acids in phospholipids were replicated, and this study also showed similar associations with phospholipids of erythrocyte membranes, but only regarding omega-6 PUFAs (Table 2B). In 2011, Lemaitre and co-authors [41] published an important GWAS from five cohorts comprising altogether 8866 individuals of European ancestry, and smaller African, Chinese, and Hispanic populations were also examined. In line with previous studies, minor alleles of FADS1 and FADS2 were associated with higher ALA but lower EPA and docosapentaenoic acid (DPA), while minor alleles of ELOVL2 were associated with higher EPA and DPA but lower DHA content. The results on FADS1 were replicated in other ancestries examined. Furthermore, this study reported a novel association of DPA with several SNPs in GCKR.

With regard to interaction, ethnicity may also have an impact on gene-diet interactions. In a study on Inuits applying GWAS, several SNPs were examined in relation to erythrocyte membrane fatty acids [42]. Novel genes and polymorphisms that modified fatty acid composition were identified (Table 2A). This study also suggests that genetic and physiological adaptation to the intake of a diet rich in omega-3 PUFAs could happen with time.

\section{Interaction between Genes and Dietary Fatty Acids}

Most of the studies on interactions between genes and dietary fat in terms of the regulation of fatty acid composition of plasma or erythrocyte membranes are based on observational studies in various 
study populations. These studies have limitations relating to the accuracy of dietary data collection and possible weaknesses associated with controlling confounding factors (e.g., age, sex, ethnicity, lifestyle factors, liver status, and cardiometabolic health). Furthermore, genetic effect on fatty acid composition may vary depending on the fatty acid biomarker used. Therefore, intervention studies may give more comprehensive data on the variation of biomarker fatty acid composition according to the genetic background. Intervention studies also have limitations. They are laborious to carry out and without a pre-genotyped study population, the screening, especially regarding rare gene variants, is demanding. In our studies, we have been able to invite participants from the large METSIM cohort with wide genotype and phenotype data [43]. A big limitation related to experimental studies with a prior hypothesis is that in intervention studies, only one preselected genetic marker can be examined at a time. Furthermore, a highly experimental diet may not reflect the effects achieved with habitual diet, and adherence to an experimental diet may remain insufficient in free-living conditions in longer-term interventions. In large-scale observational studies, a multitude of genetic variations can be examined at the same time, and it is possible to combine the data collected from different study populations or the results may be confirmed in other study populations.

Zietemann and co-authors examined the fatty acid composition of erythrocyte membranes and estimated desaturase activities in relation to the rs174546 FADS genotype variant in their cross-sectional study [44] (Table 2B). The estimated activities of FADS1 and FADS2 were strongly decreased in individuals with the minor allele, and in principle, fatty acid compositions reported were in line with earlier observations. Furthermore, this study described an interaction with diet, i.e., the dietary fatty acid n-6 to $n-3$ ratio was suggested to modify the association between the FADS1 and FADS2 genotype and estimated D5D activity calculated from measured fatty acids (see Table 1). In one study [45] (Table 2B), 309 pregnant women in the Netherlands were examined at the 36th gestational week and then one month postpartum. Both plasma phospholipids and milk fat composition postpartum were examined in relation to high fish or fish oil intakes. The results were divergent in phospholipids and milk: a higher omega-3 PUFA intake from fish or fish oil compensated for the lower DHA in plasma phospholipids irrespective of genotype, but the proportion of DHA in excreted milk remained unchanged in women who were homozygous for minor alleles of FADS1/FADS2. This study suggests that there may even be tissue-specific interactions regarding genes regulating fatty acid metabolism. Porenta and co-authors [46] (Table 2C) randomized 108 individuals with increased risk for colon cancer into the Mediterranean type diet or the Healthy Eating diet for 6 months. Serum and colonic mucosa fatty acid compositions were examined in relation to selected FADS1/FADS2 alleles. In individuals with major alleles of the FADS cluster, interaction was suggested between the diets and colonic AA content that remained unchanged after the Mediterranean diet. In a small intervention study on putative interaction between fish oil supplementation and the FADS cluster, no significant interaction was found, but fish oil supplementation resulted in greater increases in erythrocyte EPA levels in minor allele carriers of FADS1/FADS2 variants [47] (Table 2C).

In a large updated meta-analysis of the Cohorts for Heart and Aging Research in Genomic Epidemiology (CHARGE) consortium [48] (Table 2B), interaction between dietary PUFAs and 5 different genes affecting fatty acid composition was examined. However, no significant interactions were found after corrections. Interestingly, the results varied according to the compartments used. Specifically, regarding the FADS1 interaction term for ALA, even opposite effects were found in proportions of fatty acids between plasma and erythrocyte membranes.

In a small randomized cross-over trial [49], individuals homozygous for the minor allele of FADS1/FADS2 had a lower plasma AA and AA/LA ratio when compared with the major allele carriers after each diet, while ELOVL2 had no effect on PUFAs. Furthermore, flaxseed oil, which is rich in ALA, resulted in increased plasma composition of EPA beyond that of major allele homozygotes consuming a typical "western" diet (Table 2C). While very sophisticated methodologies were applied, the study design was quite complicated in this particular study. 
Table 2. Studies on the relation between genetic polymorphism and biomarkers of dietary fatty acids and reported interaction between diets and genetic variants regulating fatty acid metabolism. Part A includes genome-wide association studies (GWAS), Part B includes a priori selected genes, and Part C includes intervention studies.

\begin{tabular}{|c|c|c|c|c|}
\hline \multicolumn{5}{|l|}{ A) GWAS Studies } \\
\hline Study & Study Population and Design & Fatty Acid Biomarkers Examined & Main Findings & Comment \\
\hline $\begin{array}{l}\text { Tanaka T et al. PLoS Genet } 2009 . \\
\text { [18] }\end{array}$ & $\begin{array}{l}\text { InCHIANTI Study (Chianti region } \\
\text { of Tuscana, Italy, } n=1075 \text { ) and } \\
\text { GOLDN (predominantly } \\
\text { Caucasian, } n=1076 \text { ) } \\
\text { replication study }\end{array}$ & $\begin{array}{l}\text { PUFAs in plasma in CHIANTI } \\
\text { study and in erythrocytes in } \\
\text { GOLDN study }\end{array}$ & $\begin{array}{l}\text { FADS genetic cluster marker } \\
\text { (FADS1, FADS2, FADS3) in } \\
\text { chromosome } 11 \text { associated with } \\
\text { AA, EDA, and EPA, and EVOLV2 } \\
\text { genetic marker in chromosome } 6 \\
\text { with EPA. }\end{array}$ & $\begin{array}{l}\text { First GWAS with replication data. } \\
\text { The ELOVL2 SNP was associated } \\
\text { with DPA and DHA but not with } \\
\text { EPA in GOLDN replication study. }\end{array}$ \\
\hline $\begin{array}{l}\text { Lemaitre RN et al. } \\
\text { PLoS Genet 2011. [41] }\end{array}$ & $\begin{array}{l}\text { Five cohorts }(n=8866) \text { of European } \\
\text { ancestry (CHARGE consortium). } \\
\text { In addition, African }(n=2547), \\
\text { Chinese }(n=633) \text {, and Hispanic } \\
\text { ancestry ( }(n=661) \text { study } \\
\text { populations were examined. }\end{array}$ & $\begin{array}{l}\text { Four major } n \text { - } 3 \text { PUFAs (ALA, EPA, } \\
\text { DPA, DHA) in plasma PL }\end{array}$ & $\begin{array}{l}\text { Minor alleles of FADS1 and FADS2 } \\
\text { associated with higher ALA, } \\
\text { but lower EPA and DPA. Minor } \\
\text { alleles of SNPs in ELOVL2 were } \\
\text { associated with higher EPA and } \\
\text { DPA and lower DHA content. }\end{array}$ & $\begin{array}{l}\text { A novel association of DPA with } \\
\text { several SNPs in GCKR (glucokinase } \\
\text { regulator) was reported. Results on } \\
\text { FADS1 were similar regardless of } \\
\text { ancestry studied. }\end{array}$ \\
\hline $\begin{array}{l}\text { Wu et al. } \\
\text { Circ Cardiovasc Genet 2013. } \\
\text { CHARGE consortium [50] }\end{array}$ & European Ancestry $(n=8961)$ & $\begin{array}{l}\text { Plasma levels of 16:0, 18:0, } \\
16: 1 n-7,18: 1 n-9\end{array}$ & $\begin{array}{l}\text { ALG14 polymorphisms were } \\
\text { associated with higher 16:0 and } \\
\text { lower 18:0. FADS1 and FADS2 } \\
\text { polymorphisms were associated } \\
\text { with higher 16:1n-7 and 18:1n-9 and } \\
\text { lower 18:0. LPGAT1 } \\
\text { polymorphisms were associated } \\
\text { with lower 18:0. GCKR and } \\
\text { HIF1AN polymorphisms were } \\
\text { associated with higher 16:1n-7, } \\
\text { whereas } P K D 2 L 1 \text { and a locus on } \\
\text { chromosome } 2 \text { (not near known } \\
\text { genes) were associated with } \\
\text { lower 16:1n-7. }\end{array}$ & $\begin{array}{l}\text { Polymorphisms in } 7 \text { novel loci were } \\
\text { associated with circulating levels of } \\
\geq 1 \text { of } 16: 0,18: 0,16: 1 n-7,18: 1 n-9 \text {. }\end{array}$ \\
\hline $\begin{array}{l}\text { Guan et al. } \\
\text { Circ Cardiovasc Genet 2014. [51] }\end{array}$ & White adults $(n=8631)$ & $\begin{array}{l}\text { Total plasma or plasma } \\
\text { PL } n-6 \text { PUFAs }\end{array}$ & $\begin{array}{l}\text { Novel regions were identified } \\
\text { on chromosome } 10 \text { associated with } \\
\text { LA (rs10740118; near NRBF2); } \\
\text { on chromosome } 16 \text { with LA, GLA, } \\
\text { dihomo-GLA, and AA (rs16966952; } \\
\text { NTAN1); and on chromosome } 6 \\
\text { with adrenic acid after adjustment } \\
\text { for AA (rs3134950; AGPAT1). } \\
\text { Previous findings of the FADS } \\
\text { cluster on chromosome } 11 \text { with LA } \\
\text { and AA were confirmed. }\end{array}$ & \\
\hline $\begin{array}{l}\text { Dorajoo R et al. } \\
\text { Genes Nutr. 2015. [52] }\end{array}$ & $\begin{array}{l}\text { Singaporean Chinese population } \\
(n=1361)\end{array}$ & Plasma PUFAs & $\begin{array}{l}\text { Genome-wide associations with } \\
\text { ALA, all four } n-6 \text { PUFAs, } \\
\text { and delta-6 desaturase activity at } \\
\text { the FADS1/FADS2 locus. These } \\
\text { associations were independent of } \\
\text { dietary intake of PUFAs. }\end{array}$ & $\begin{array}{l}\text { Genetic loci that influence plasma } \\
\text { concentrations of } n-3 \text { and } n-6 \\
\text { PUFAs are shared across different } \\
\text { ethnic groups. }\end{array}$ \\
\hline
\end{tabular}


Table 2. Cont.

\begin{tabular}{|c|c|c|c|c|c|}
\hline $\begin{array}{l}\text { Fumagalli M et al. } \\
\text { Science 2015. [42] }\end{array}$ & $\begin{array}{l}\text { Inuits }(n=191) \text {, European }(n=60) \text {, } \\
\text { and Han Chinese }(n=44) \\
\text { individuals }\end{array}$ & Erythrocyte membrane fatty acids & & $\begin{array}{l}\text { FADS1, FADS2, FADS3, and SNPs } \\
7115739 \text {, rs174570 (among others) } \\
\text { had positive association with ETA, } \\
\text { but negative associations with EPA } \\
\text { and DPA; no effect on DHA } \\
\text { content. }\end{array}$ & $\begin{array}{l}\text { Novel genes and polymorphisms } \\
\text { were identified in Inuits that may } \\
\text { suggest genetic and physiological } \\
\text { adaptation to a } \\
\text { high-omega-3-PUFA diet; } \\
\text { associations with height and } \\
\text { weight were also found. }\end{array}$ \\
\hline $\begin{array}{l}\text { Lemaitre et al. } \\
\text { J Lipid Res 2015. [53] }\end{array}$ & European ancestry $(n=10,129)$ & $\begin{array}{l}\text { Plasma PL and Erythrocyte levels } \\
\text { of VLSFA }(20: 0,22: 0,24: 0)\end{array}$ & & $\begin{array}{l}\text { The SPTLC3 (serine } \\
\text { palmitoyl-transferase long-chain } \\
\text { base subunit 3) variant at rs680379 } \\
\text { was associated with higher 20:0. } \\
\text { The CERS4 (ceramide synthase 4) } \\
\text { variant at rs2100944 was associated } \\
\text { with higher levels of 20:0 and in } \\
\text { analyses that adjusted for 20:0, } \\
\text { with lower levels of 22:0 and 24:0. }\end{array}$ & $\begin{array}{l}\text { SPTLC3 is a gene involved in the } \\
\text { rate-limiting step of de novo } \\
\text { sphingolipid synthesis. }\end{array}$ \\
\hline $\begin{array}{l}\text { Mozaffarian et al. } \\
\text { Am J Clin Nutr } 2015 . \\
\text { CHARGE consortium [54] }\end{array}$ & $\begin{array}{l}\text { Meta-analysis of GWA studies } \\
(n=8013)\end{array}$ & $\begin{array}{l}\text { Erythrocyte of PL trans fatty acids } \\
\text { and } 31 \text { SNPs in or near the FADS1 } \\
\text { and FADS2 cluster }\end{array}$ & & $\begin{array}{l}\text { Genetic regulation of cis/trans-18:2 } \\
\text { by the FADS1/2 cluster. }\end{array}$ & Trans fatty acids. \\
\hline $\begin{array}{l}\text { Tintle NL et al. } \\
\text { Prostaglandins Leukot Essent } \\
\text { Fatty Acids 2015. [55] }\end{array}$ & $\begin{array}{l}\text { Framingham Offspring Study } \\
(n=2633)\end{array}$ & 14 red blood cell fatty acids & & $\begin{array}{l}\text { Novel associations between (1) AA } \\
\text { and PCOLCE2 (regulates apoA-I } \\
\text { maturation and modulates apoA-I } \\
\text { levels), and (2) oleic and linoleic } \\
\text { acid and LPCAT3 (mediates the } \\
\text { transfer of fatty acids between } \\
\text { glycerolipids). Also, previously } \\
\text { identified strong associations } \\
\text { between SNPs in the FADS and } \\
\text { ELOVL regions were replicated. }\end{array}$ & $\begin{array}{l}\text { Multiple SNPs explained } 8-14 \% \text { of } \\
\text { the variation in } 3 \text { high-abundance } \\
(>11 \%) \text { fatty acids, but only } 1-3 \% \text { in } \\
4 \text { low-abundance }(<3 \%) \text { fatty acids, } \\
\text { with the notable exception of } \\
\text { DGLA acid with } 53 \% \text { of variance } \\
\text { explained by SNPs. }\end{array}$ \\
\hline $\begin{array}{l}\text { de Oliveira Otto MC et al. } \\
\text { CHARGE consortium. } \\
\text { PLoS One 2018. [56] }\end{array}$ & $\begin{array}{l}\text { Meta-analysis of GWA studies } \\
(n=11,494) ; \text { individuals of } \\
\text { European descent }\end{array}$ & $\begin{array}{l}\text { 15:0, 17:0, 19:0, and 23:0 (OCSFA) in } \\
\text { plasma PL and erythrocytes }\end{array}$ & & $\begin{array}{l}\text { SNP MYO10 rs } 13361131 \text { associated } \\
\text { with 17:0 level, DLEU1 rs12874278 } \\
\text { and rs 17363566 associated with } \\
\text { 19:0 level. Using candidate gene } \\
\text { approach, a few other SNPs also } \\
\text { associated with 17:0 and 23:0 levels. }\end{array}$ & $\begin{array}{l}\text { Circulating levels of OCSFA are } \\
\text { predominantly influenced by } \\
\text { nongenetic factors. }\end{array}$ \\
\hline \multicolumn{6}{|l|}{ B) Candidate Gene Studies } \\
\hline Study & Study Population and Design & Fatty Acid Biomarkers Examined & Genes Examined & Main Findings & Comment \\
\hline $\begin{array}{l}\text { Schaeffer L et al. } \\
\text { Hum Mol Genet 2006. [39] }\end{array}$ & $\begin{array}{l}N=727 \text { from Erfurt, Germany, } \\
\text { from The European Community } \\
\text { Respiratory Health Survey I } \\
\text { (ECRHS I), cross-sectional }\end{array}$ & PUFAs in plasma PL & $\begin{array}{l}\text { Haplotypes of FADS1 and } \\
\text { FADS2 region }\end{array}$ & $\begin{array}{l}\text { Haplotypes of FADS1 and FADS2 } \\
\text { region associated with AA and } \\
\text { many other long-chain } n-6 \text { and } n-3 \\
\text { fatty acids (e.g., LA, GLA, and EPA } \\
\text { and DPA. }\end{array}$ & $\begin{array}{l}\text { Mostly decreased levels of PUFAs } \\
\text { associated with minor alleles of } \\
\text { FADS1 and FADS2. }\end{array}$ \\
\hline
\end{tabular}


Table 2. Cont

\begin{tabular}{|c|c|c|c|c|c|}
\hline $\begin{array}{l}\text { Xie L and Innis SM. } \\
\text { J Nutr 2008. [57] }\end{array}$ & $\begin{array}{l}69 \text { pregnant women in Canada and } \\
\text { breast milk for a subset of } 54 \\
\text { women exclusively breast-feeding } \\
\text { at } 1 \text { month postpartum, } \\
\text { cross-sectional }\end{array}$ & $\begin{array}{l}\text { Plasma phospholipid and } \\
\text { erythrocyte ethanolamine } \\
\text { phosphoglyceride (EPG) }(n-6) \\
\text { and }(n-3) \text { fatty acids }\end{array}$ & $\begin{array}{l}\text { FADS1/FADS2 } \\
\text { rs174553, rs99780, rs174575, } \\
\text { and rs174583 }\end{array}$ & $\begin{array}{l}\text { Minor allele homozygotes of } \\
\text { rs174553 (GG), rs99780 (TT), } \\
\text { and rs174583 (TT) had lower AA } \\
\text { but higher LA in plasma } \\
\text { phospholipids and erythrocyte } \\
\text { EPG and decreased ( } n-6) \text { and }(n-3) \\
\text { fatty acid product/precursor ratios } \\
\text { at } 16 \text { and } 36 \text { weeks of gestation. }\end{array}$ & $\begin{array}{l}\text { Breast milk fatty acids were } \\
\text { influenced by genotype, } \\
\text { with significantly lower 14:0, AA, } \\
\text { and EPA but higher 20:2( } n-6) \text { in the } \\
\text { minor allele homozygotes of } \\
\text { rs174553, rs99780, and rs174583 } \\
\text { and lower AA, EPA, DPA, } \\
\text { and DHA in the minor allele } \\
\text { homozygotes of rs174575. }\end{array}$ \\
\hline $\begin{array}{l}\text { Rzehak P et al. } \\
\text { Br J Nutr 2009. [40] }\end{array}$ & $\begin{array}{l}\text { Bavarian Nutrition survey II, } \\
\text { Germany, cross-sectional, }(n=163 \\
\text { and } n=535)\end{array}$ & $\begin{array}{l}\text { Phospholipid PUFA in plasma } \\
(n=163) \text {, erythrocyte membranes } \\
(n=535)\end{array}$ & FADS1 and FADS2 haplotypes & $\begin{array}{l}\text { Replication of FADS1 and FADS2 } \\
\text { haplotypes associations in } \\
\text { phospholipids (Schaeffer et al. } \\
\text { 2006) and associations with PUFA } \\
\text { in membranes. }\end{array}$ & $\begin{array}{l}\text { Association with cell membranes } \\
\text { was a novel finding. } \\
\text { No associations with } \\
\text { omega-3 PUFA. }\end{array}$ \\
\hline $\begin{array}{l}\text { Molto-Puigmarti C et al. } \\
\text { Am J Clin Nutr 2010. [45] }\end{array}$ & $\begin{array}{l}\text { KOALA Birth Cohort Study in } \\
\text { the Netherlands. } \\
\text { Plasma samples were collected at } \\
\text { 36th gestational week in pregnant } \\
\text { women }(N=309) \text { and milk samples } \\
\text { at } 1 \text { month postpartum. }\end{array}$ & $\begin{array}{l}\text { Plasma phospholipids and milk } \\
\text { DHA proportion }\end{array}$ & $\begin{array}{l}\text { FADS1 rs174561, FADS2 rs174575, } \\
\text { and intergenic rs } 3834458\end{array}$ & $\begin{array}{l}\text { A higher fish (or fish oil) intake } \\
\text { compensated for the lower DHA } \\
\text { proportions in plasma } \\
\text { phospholipids irrespective of } \\
\text { genotype but not in the milk from } \\
\text { women with minor allele carriers of } \\
\text { selected gene variants. }\end{array}$ & $\begin{array}{l}\text { The study confirms earlier studies } \\
\text { with regard to PUFA associations } \\
\text { with minor allele carriers. Novelty } \\
\text { of this study was gene-diet } \\
\text { interaction regarding milk fat; } \\
\text { DHA content remained unchanged } \\
\text { with increasing fish/fish oil intake } \\
\text { in women homozygous for } \\
\text { minor allele. }\end{array}$ \\
\hline $\begin{array}{l}\text { Zietemann V et al. } \\
\text { Br J Nutr 2010. [44] }\end{array}$ & $\begin{array}{l}\text { A random sample of } 2066 \\
\text { participants from the European } \\
\text { Prospective Investigation into } \\
\text { Cancer and Nutrition-Potsdam } \\
\text { study, cross-sectional }\end{array}$ & $\begin{array}{l}\text { Erythrocyte membrane fatty acids } \\
\text { and estimated desaturase activity }\end{array}$ & $\begin{array}{l}\text { rs174546 genetic variation } \\
\text { (reflecting genetic variation in the } \\
\text { FADS1/FADS2 gene cluster) }\end{array}$ & $\begin{array}{l}\text { Higher proportions of LA, EDA, } \\
\text { and DGLA and lower proportions } \\
\text { of GLA, AA, and DTA for the } \\
\text { minor allele carriers. The estimated } \\
\text { activities of FADS1 and FADS2 } \\
\text { strongly decreased with } \\
\text { minor T-allele. }\end{array}$ & $\begin{array}{l}\text { Interaction with diet; dietary } \\
n-6 / n-3 \text { ratio was suggested to } \\
\text { modify the association between the } \\
\text { FADS1/ FADS2 genotype and the } \\
\text { estimated D5D activity. }\end{array}$ \\
\hline $\begin{array}{l}\text { Dumont J et al. } \\
\text { J Nutr 2011. [58] }\end{array}$ & $\begin{array}{l}\text { European adolescents, HELENA } \\
\text { study }(n=573) \text {, cross-sectional }\end{array}$ & $\begin{array}{l}\text { Dietary intake of LA and ALA } \\
\text { ALA, PUFA levels in serum PL } \\
\text { Serum concentrations of TG, } \\
\text { cholesterol, and lipoproteins }\end{array}$ & FADS1 rs174546 & $\begin{array}{l}\text { The associations between FADS1 } \\
\text { rs174546 and concentrations of } \\
\text { PUFA, TG, cholesterol, } \\
\text { and lipoproteins were not affected } \\
\text { by dietary LA intake. Similarly, } \\
\text { the association between the FADS1 } \\
\text { rs174546 polymorphism and serum } \\
\text { phospholipid concentrations of } \\
\text { ALA or EPA was not modified by } \\
\text { dietary ALA intake. In contrast, } \\
\text { the rs174546 minor allele was } \\
\text { associated with lower total } \\
\text { cholesterol concentrations and } \\
\text { non-HDL cholesterol } \\
\text { concentrations in the } \\
\text { high-ALA-intake group but not in } \\
\text { the low-ALA-intake group. }\end{array}$ & $\begin{array}{l}\text { These results suggest that dietary } \\
\text { ALA intake modulates the } \\
\text { association between FADS1 } \\
\text { rs174546 and serum total and } \\
\text { non-HDL cholesterol } \\
\text { concentrations at a young age. }\end{array}$ \\
\hline
\end{tabular}


Table 2. Cont

\begin{tabular}{|c|c|c|c|c|c|}
\hline $\begin{array}{l}\text { Merino et al. } \\
\text { Mol Genet Metab. 2011. [59] }\end{array}$ & $\begin{array}{l}\text { Toronto Nutrigenomics and Health } \\
\text { study, (Caucasians } n=78, \text { Asian, } \\
n=69) \text {, cross-sectional }\end{array}$ & Plasma fatty acids & $\begin{array}{l}\text { FADS1 and FADS2 genotypes } \\
\text { (19 SNPs) }\end{array}$ & $\begin{array}{l}\text { The most significant association } \\
\text { was between the FADS1 rs174547 } \\
\text { and AA/LA in both Caucasians } \\
\text { and Asians. Although the minor } \\
\text { allele for this SNP differed between } \\
\text { Caucasians (T) and Asians (C), } \\
\text { carriers of the C allele had a lower } \\
\text { desaturase activity than carriers of } \\
\text { the T allele in both groups. }\end{array}$ & \\
\hline $\begin{array}{l}\text { Hong et al. } \\
\text { Clin Interv Aging 2013. [60] }\end{array}$ & $\begin{array}{l}3 \text { years follow-up study, nonobese } \\
\text { men in South Korea }(n=122)\end{array}$ & Serum PL PUFAs & $\begin{array}{l}\text { near FADS1 rs174537; FEN1 } \\
\text { rs174537G; FADS2 rs174575 and } \\
\text { rs2727270; FADS3 rs1000778 }\end{array}$ & $\begin{array}{l}\text { The minor variants of rs174537 and } \\
\text { rs } 2727270 \text { were significantly } \\
\text { associated with lower } \\
\text { concentrations of } \\
\text { long-chain PUFAs. }\end{array}$ & $\begin{array}{l}\text { FADS polymorphisms can affect } \\
\text { age-associated changes in serum } \\
\text { phospholipid long-chain PUFAs, } \\
\Delta 5 \text {-desaturase activity, } \\
\text { and oxidative stress. }\end{array}$ \\
\hline $\begin{array}{l}\text { Roke K et al. } \\
\text { Prostaglandins Leukot Essent } \\
\text { Fatty Acids 2013. [61] }\end{array}$ & $\begin{array}{l}\text { Cross-sectional study, healthy } \\
\text { young adults in Canada ( } n=878)\end{array}$ & $\begin{array}{l}\text { Plasma levels of LA, GLA, DGLA, } \\
\text { and AA }\end{array}$ & $\begin{array}{l}\text { FADS1/2 } \\
\text { rs174579, rs174593, rs174626, } \\
\text { rs526126, rs968567 and rs17831757 }\end{array}$ & $\begin{array}{l}\text { Several SNPs were associated with } \\
\text { circulating levels of individual FAs } \\
\text { and desaturase indices, with minor } \\
\text { allele carriers having lower AA } \\
\text { levels and reduced } \\
\text { desaturase indices. }\end{array}$ & $\begin{array}{l}\text { A single SNP in FADS2 (rs526126) } \\
\text { was weakly associated with hsCRP. }\end{array}$ \\
\hline Huang et al. Nutrition 2014. [62] & $\begin{array}{l}\text { T2DM patients }(n=758) \text { and } \\
\text { healthy individuals }(n=400) \text { in } \\
\text { Han Chinese, cross-sectional }\end{array}$ & Erythrocyte PL Fatty acids & $\begin{array}{l}\text { Genetic variants in the FADS } \\
\text { gene cluster }\end{array}$ & $\begin{array}{l}\text { Minor allele homozygotes and } \\
\text { heterozygotes of rs174575 and } \\
\text { rs174537 had lower AA levels in } \\
\text { healthy individuals. Minor allele } \\
\text { homozygotes and heterozygotes of } \\
\text { rs174455 in FADS3 gene had lower } \\
\text { levels of DPA, AA, } \\
\text { and } \triangle 5 \text { desaturase activity in } \\
\text { patients with T2DM. }\end{array}$ & \\
\hline $\begin{array}{l}\text { Smith CE et al. } \\
\text { Mol Nutr Food Res 2015. [48] }\end{array}$ & $\begin{array}{l}\text { Updated meta-analysis of } \\
\text { CHARGE consortium }(n=11,668) \\
\text { evaluating interactions between } \\
\text { dietary PUFAs and selected genetic } \\
\text { variants of } 5 \text { genes }\end{array}$ & $\begin{array}{l}\text { Total plasma, phospholipids or } \\
\text { erythrocyte membranes ALA, EPA, } \\
\text { DHA, and DPA } \\
\text { Dietary PUFA }\end{array}$ & $\begin{array}{l}\text { FADS1 rs174538 and rs174548; } \\
\text { AGPAT3 rs7435; PDXDC1 } \\
\text { rs4985167; GCKR rs780094; } \\
\text { ELOVL2 rs3734398 }\end{array}$ & $\begin{array}{l}\text { Primary aim was to examine } \\
\text { gene-diet interactions regarding } \\
\text { PUFAs. No significant interactions } \\
\text { were found after corrections. }\end{array}$ & $\begin{array}{l}\text { Fatty acid compartments affected } \\
\text { the results, and, e.g., FADS1 } \\
\text { interaction terms for dietary ALA } \\
\text { vs plasma phospholipids (negative) } \\
\text { and erythrocytes (positive) } \\
\text { were opposite. }\end{array}$ \\
\hline $\begin{array}{l}\text { Andersen et al. } \\
\text { PLoS Genet 2016. [63] }\end{array}$ & $\begin{array}{l}\text { Cross-sectional, Greenlanders } \\
(n=2626)\end{array}$ & $\begin{array}{l}22 \text { FAs in the PL fraction in } \\
\text { erythrocytemembranes }\end{array}$ & $\begin{array}{l}\text { ACSL6 rs76430747; DTD1 } \\
\text { rs6035106; CPT1A rs80356779; } \\
\text { FADS2 rs174570; LPCAT3 } \\
\text { rs2110073; CERS4 rs11881630 }\end{array}$ & $\begin{array}{l}\text { Novel loci were identified on } \\
\text { chromosomes } 5 \text { and } 11 \text {, showing } \\
\text { strongest association with oleic } \\
\text { acid (ACSL6) and DHA (DTD1), } \\
\text { respectively. For a missense variant } \\
\text { (in } C P T 1 A) \text {, a number of novel FA } \\
\text { associations were identified; } \\
\text { the strongest with } \\
\text { 11-eicosenoic acid. }\end{array}$ & $\begin{array}{l}\text { Novel loci associating with FAs in } \\
\text { the PL fraction of } \\
\text { erythrocytemembranes were } \\
\text { identified in Greenlanders. } \\
\text { For variants in FADS2, LPCAT3, } \\
\text { and CERS4, known FA associations } \\
\text { were replicated. }\end{array}$ \\
\hline
\end{tabular}


Table 2. Cont.

\begin{tabular}{|c|c|c|c|c|c|}
\hline $\begin{array}{l}\text { Takkunen M et al. } \\
\text { Mol Nutr Food Res 2016. [64] }\end{array}$ & $\begin{array}{l}962 \text { men from the METSIM study } \\
\text { and Kuopio Obesity Surgery Study } \\
\text { participants }(n=240) \text { in Finland, } \\
\text { cross-sectional }\end{array}$ & $\begin{array}{l}\text { Fatty acid composition in } \\
\text { erythrocyte and plasma PL, CE, } \\
\text { and TG }\end{array}$ & $\begin{array}{l}\text { Hepatic expression of FADS1 } \\
\text { (rs174547/rs174550) }\end{array}$ & $\begin{array}{l}\text { A common FADS1 variant } \\
\text { (rs 174550) showed nominally } \\
\text { significant gene-diet interactions } \\
\text { between EPA in erythrocytes, } \\
\text { and plasma CE and TG and } \\
\text { dietary intakes. }\end{array}$ & $\begin{array}{l}\text { Minor allele (C) of FADS1 } \\
\text { (rs174547) was strongly associated } \\
\text { with reduced hepatic mRNA } \\
\text { expression. High intake of EPA and } \\
\text { DHA may reduce D5D activity in } \\
\text { the liver. }\end{array}$ \\
\hline $\begin{array}{l}\text { de la Garza Puentes A et al. } \\
\text { PLoS ONE 2017. [65] }\end{array}$ & $\begin{array}{l}\text { PREOBE cohort in Spain }(n=180) \text {, } \\
24 \text { weeks of gestation, } \\
\text { cross-sectional }\end{array}$ & Plasma PL FAs & $\begin{array}{l}7 \text { SNPs in FADS1, } 5 \text { in FADS2, } \\
3 \text { in ELOVL2 and } 2 \text { in ELOVL5 }\end{array}$ & $\begin{array}{l}\text { Normal-weight women who were } \\
\text { minor allele carriers of FADS SNPs } \\
\text { had lower levels of AA, lower } \\
\text { AA/DGLA and AA/LA indices, } \\
\text { and higher levels of DGLA } \\
\text { compared to major homozygotes. } \\
\text { Among minor allele carriers of } \\
\text { FADS2 and ELOVL2 SNPs, } \\
\text { overweight/obese women showed } \\
\text { a higher DHA/EPA index than the } \\
\text { normal-weight group. }\end{array}$ & $\begin{array}{l}\text { Maternal weight modifies the effect } \\
\text { of genotype on FA levels. }\end{array}$ \\
\hline $\begin{array}{l}\text { Guo H et al. } \\
\text { Lipids Health Dis 2017. [66] }\end{array}$ & 951 Chinese adults, cross-sectional & $\begin{array}{l}\text { Plasma PL FAs } \\
\text { FADS1 rs174547 }\end{array}$ & FADS1 rs174547 & $\begin{array}{l}\text { The rs174547 C minor allele was } \\
\text { associated with a higher proportion } \\
\text { of LA, lower AA and DHA, as well } \\
\text { as lower delta-6-desaturase and } \\
\text { delta-5-desaturase activities. }\end{array}$ & $\begin{array}{l}\text { Confirms earlier finding in } \\
\text { Chinese population. }\end{array}$ \\
\hline $\begin{array}{l}\text { Kim et al. } \\
\text { Prostaglandins Leukot Essent } \\
\text { Fatty Acids 2018. [67] }\end{array}$ & $\begin{array}{l}\text { Three-year prospective cohort } \\
\text { study in Korea, } 287 \text { healthy subjects }\end{array}$ & Plasma PUFA levels & FADS1 rs174547 & $\begin{array}{l}\text { The minor allele of the FADS1 } \\
\text { rs174547 associated with } \\
\text { age-related decrease in the } \\
\text { EPA/AA ratio among } \\
\text { overweight subjects. }\end{array}$ & $\begin{array}{l}\text { The minor allele of the FADS } 1 \\
\text { rs174547 associated with increase } \\
\text { in arterial stiffness among } \\
\text { overweight subjects. }\end{array}$ \\
\hline $\begin{array}{l}\text { Li et al. } \\
\text { Am J Clin Nutr 2018. [68] }\end{array}$ & $\begin{array}{l}1504 \text { healthy Chinese adults, } \\
\text { cross-sectional }\end{array}$ & Plasma PUFA concentration & FADS2 rs66698963 & $\begin{array}{l}\text { The rs66698963 genotype is } \\
\text { associated with AA concentration } \\
\text { and AA to EPA+DHA ratio. }\end{array}$ & $\begin{array}{l}\text { Genotype also affected triglyceride } \\
\text { and HDL } \\
\text { cholesterol concentrations. }\end{array}$ \\
\hline \multicolumn{6}{|l|}{ C) Intervention Studies } \\
\hline Study & Study Population and Design & Fatty Acid Biomarkers Examined & Genes Examined & Main Findings & COMMENT \\
\hline $\begin{array}{l}\text { Al-Hilal M et al. } \\
\text { J Lipid Res 2013. [69] }\end{array}$ & $\begin{array}{l}\text { RCT in United Kingdom }(n=310) \\
\text { Supplementation of EPA + DHA } \\
\text { 1) } 0.45 \mathrm{~g} / \text { day } \\
\text { 2) } 0.9 \mathrm{~g} / \text { day } \\
\text { 3) } 1.8 \mathrm{~g} / \text { day } \\
\text { 4) placebo } \\
\text { for } 6 \text { months }\end{array}$ & Plasma and erythrocyte PUFAs & $\begin{array}{l}\text { FADS1/FADS2 } \\
\text { rs174537, rs174561, and rs3834458 }\end{array}$ & $\begin{array}{l}\text { s174537, rs174561, and rs3834458 in } \\
\text { the FADS1-FADS 2 gene cluster } \\
\text { were strongly associated with } \\
\text { proportions of LC-PUFAs and } \\
\text { desaturase activities estimated in } \\
\text { plasma and Ery. In a randomized } \\
\text { controlled dietary intervention, } \\
\text { increasing EPA and } \\
\text { docosahexaenoic acid DHA intake } \\
\text { significantly increased D5D and } \\
\text { decreased D6D activity after doses } \\
\text { of } 0.45,0.9 \text {, and } 1.8 \mathrm{~g} / \text { day for six } \\
\text { months. Interaction of rs174537 } \\
\text { genotype with treatment was a } \\
\text { determinant of D5D activity } \\
\text { estimated in plasma. }\end{array}$ & $\begin{array}{l}\text { Different sites at the FADS1-FADS2 } \\
\text { locus appear to influence D5D and } \\
\text { D6D activity, and rs174537 } \\
\text { genotype interacts with dietary } \\
\text { EPA+DHA to modulate D5D. }\end{array}$ \\
\hline
\end{tabular}


Table 2. Cont.

\begin{tabular}{|c|c|c|c|c|c|}
\hline $\begin{array}{l}\text { Gillingham LG et al. } \\
\text { Am J Clin Nutr 2013. [49] }\end{array}$ & $\begin{array}{l}36 \text { hyperlipidemic individuals in } \\
\text { Canada, randomized cross-over } \\
\text { design with } 3 \text { experimental diets } \\
\text { for } 4 \text { weeks } \\
\text { 1) Flax seed oil } \\
\text { 2) High canola oil } \\
\text { 3) Western diet } \\
\text { Only a few persons with minor } \\
\text { allele of a given gene }\end{array}$ & $\begin{array}{l}\text { Plasma FAs and }\left(\mathrm{U}-{ }^{13} \mathrm{C}\right) \\
\text { ALA metabolism }\end{array}$ & $\begin{array}{l}\text { SNPs for FADS1, } \\
\text { FADS2 and ELOVL2 }\end{array}$ & $\begin{array}{l}\text { Subjects homozygous for the minor } \\
\text { allele of FADS1/FADS2 had lower } \\
\text { plasma composition of AA and } \\
\text { AA/LA ratio in comparison with } \\
\text { the major allele carriers after } \\
\text { consumption of each experimental } \\
\text { diet. ELOVL2 had no effect } \\
\text { on PUFAs. }\end{array}$ & $\begin{array}{l}\text { Increasing ALA intake with a diet } \\
\text { enriched in flaxseed oil in minor } \\
\text { allele homozygotes resulted in an } \\
\text { increased plasma composition of } \\
\text { EPA beyond that of major allele } \\
\text { homozygotes consuming a typical } \\
\text { western diet. }\end{array}$ \\
\hline $\begin{array}{l}\text { Porenta SR et al. } \\
\text { Cancer Prev Res (Phila) 2013. [46] }\end{array}$ & $\begin{array}{l}108 \text { individuals with increased risk } \\
\text { of colon cancer in USA, RCT for } \\
6 \text { months with two } \\
\text { intervention diets: } \\
\text { 1) Mediterranean type (MedD) } \\
\text { 2) Heathy Eating Diet }\end{array}$ & $\begin{array}{l}\text { Serum and colonic mucosa } \\
\text { fatty acids }\end{array}$ & $\begin{array}{l}\text { FADS1 / FADS2 minor allele SNPs } \\
\text { (rs174556, rs174561, } \\
\text { rs174537, rs3834458) }\end{array}$ & $\begin{array}{l}\text { At } 6 \text { months, an increase in colonic } \\
\text { AA in the Healthy Eating diet arm } \\
\text { was found, while colon AA } \\
\text { concentrations remained fairly } \\
\text { constant in the MedD group in } \\
\text { persons with major alleles in the } \\
\text { FADS1/2 gene cluster. }\end{array}$ & $\begin{array}{l}\text { These results suggest gene-diet } \\
\text { interaction in fatty acid metabolism } \\
\text { related to different response to } \\
\text { diets, but in individuals with major } \\
\text { alleles of the FADS cluster. }\end{array}$ \\
\hline $\begin{array}{l}\text { Roke K and Mutch DM. } \\
\text { Nutrients 2014. [47] }\end{array}$ & $\begin{array}{l}12 \text { young men in Canada, } 12 \text { week } \\
\text { intervention with fish oil capsules } \\
\text { with } 8 \text { week wash-out; } \\
\text { no control group }\end{array}$ & $\begin{array}{l}\text { Fatty acid analysis from serum } \\
\text { and erythrocytes }\end{array}$ & FADS1/FADS2 (rs174537, rs174576) & $\begin{array}{l}\text { Marked increase in serum and } \\
\text { erythrocyte EPA and DHA. } \\
\text { Elevation in RBC was sustained for } \\
8 \text { weeks during wash-out. }\end{array}$ & $\begin{array}{l}\text { No significant gene } \times \text { fish oil } \\
\text { interaction, but } \% \text { change in minor } \\
\text { allele carriers of FADS1/FADS2 } \\
\text { had a greater increase in RBC } \\
\text { EPA levels. }\end{array}$ \\
\hline $\begin{array}{l}\text { Scholtz SA et al. } \\
\text { Prostaglandins Leukot Essent } \\
\text { Fatty Acids 2015. [70] }\end{array}$ & $\begin{array}{l}\text { Intervention, pregnant women } \\
(n=205) \text { in USA } \\
\text { 1) Supplementation with } 600 \mathrm{mg} \\
\text { per day of DHA } \\
\text { 2) Placebo for the last two } \\
\text { trimesters of pregnancy }\end{array}$ & Plasma and RBC PL AA and DHA & $\begin{array}{l}\text { FADS1 rs174533 and } \\
\text { FADS2 rs174575 }\end{array}$ & $\begin{array}{l}\text { DHA but not the placebo decreased } \\
\text { the AA status of minor allele } \\
\text { homozygotes of both FADS SNPs } \\
\text { but not major allele homozygotes } \\
\text { at delivery. }\end{array}$ & \\
\hline $\begin{array}{l}\text { Lankinen et al. } \\
\text { Am J Clin Nutr 2018. (in press) }\end{array}$ & $\begin{array}{l}\text { Intervention, men with FADS1 } \\
\text { rs174550 TT or CC genotype } \\
(n=59) \text { in Finland } \\
\text { High-LA diet for } 4 \text { weeks }\end{array}$ & Plasma PL and CE fatty acids & FADS1 rs174550 & $\begin{array}{l}\text { There was a significant increase in } \\
\text { the LA proportion in PL and CE in } \\
\text { both genotype groups. } \\
\text { A significant interaction between } \\
\text { intervention and genotype was } \\
\text { observed in AA, (decreased in CC } \\
\text { genotype, but remained unchanged } \\
\text { (in PL) or decreased only slightly } \\
\text { (in CE) in TT genotype). }\end{array}$ & $\begin{array}{l}\text { The response to higher LA intake } \\
\text { in hsCRP was different between the } \\
\text { genotypes. Individuals with the } \\
\text { rs174550-TT genotype had a trend } \\
\text { towards decreased hsCRP, while } \\
\text { individuals with the rs174550-CC } \\
\text { genotype had a trend towards } \\
\text { increased hsCRP (significant diet } \times \\
\text { genotype interaction). }\end{array}$ \\
\hline
\end{tabular}

Abbreviations: AA, arachidonic acid (20:4n-6); ALA, alpha-linolenic acid (18:3n-3); DGLA; Di-homo-gamma linolenic acid (20:3n-6); DPA, docosapentaenoic acid (22:5n-3); EDA, eicosadienoic acid (20:2n-6); EPA, eicosapentaenoic acid (20:5n-3); Ery, erythrocyte membranes; ETA, eicosatetraenoic acid (20:4n-3); hsCRP; high-sensitivity C-reactive protein; GLA, gamma-linolenic acid (18:3n-6); LA, linoleic acid (18:2n-6), OCSFA; odd-chain saturated fatty acids; PL, phospholipid; PUFA, polyunsaturated fatty acid; RBC, red blood cell; RCT, randomized controlled trial; SNP, single-nucleotide polymorphism; T2D, type 2 diabetes; VLSFA, very-long-chain saturated fatty acids. 
In one of our own cross-sectional studies [64], we reported a nominally significant gene-diet interaction between EPA in erythrocytes, CE and TG, and dietary intake of EPA in 962 men who were participating in the METSIM study (Table 2B). Interestingly, exclusion of fish oil supplement users strengthened the observed interaction with diet. We also confirmed that the minor allele of rs174550 of FADS1 (C allele) was strongly associated with a lower hepatic mRNA expression, as observed recently by Wang et al. in their cross-sectional study [71]. Thus, we concluded that the observed interaction could be explained by divergent activity of the liver D5D enzyme in the genetic variants of FADS examined in our study.

Ideally, gene-diet interaction would be studied using an intervention design with participants with pre-selected genotypes. In our recent trial (Lankinen et al., Am J Clin Nutr 2018, in press), our aim was to test the hypothesis that the FADS1 rs174550 genotype modifies the effect of dietary LA intake on the fatty acid composition of plasma lipids. Altogether, 59 men who were homozygotes for FADS1 rs174550 SNP (TT or CC) completed the 4-week dietary intervention with a diet enriched in LA. During the 4-week intervention period, participants consumed their habitual diet with a supplement of $30 \mathrm{~mL}$, $40 \mathrm{~mL}$, or $50 \mathrm{~mL}$ (27-45 g) sunflower oil daily depending on their BMI. The doses of sunflower oil provided 17-28 g (6 E\%) LA daily on top of the average intake of approximately 10-12 g (4.5 E\%). The response in the proportion of AA in plasma phospholipids and cholesteryl esters differed between the genotype groups (Table 2C). The proportion of AA decreased in participants with the CC genotype, but remained unchanged (in PL) or decreased only slightly (in CE) in participants with the TT genotype. We also found that the FADS1 genotype modified the lipid mediator profile (including eicosanoids and oxylipins) and inflammatory response, measured as serum high-sensitivity $\mathrm{C}$-reactive protein, to an LA-rich diet.

\section{Concluding Remarks}

In this review, we aimed to summarize the current evidence regarding genes and dietary fatty acids in the regulation of the fatty acid composition of plasma lipids and erythrocyte membranes. The knowledge related to this topic has increased markedly during recent years, but there is no earlier review article compiling it together. The fatty acid composition of blood lipids and tissues is modified by dietary intake, but endogenous metabolism of fatty acids, which is strongly genetically regulated, also has an important role. In particular, genetic variants of the FADS gene cluster in chromosome 11 and elongases (ELOVLs) are involved in the regulation of fatty acid metabolism. In recent years, some new genetic variants have been shown to be associated with the fatty acid composition of plasma lipids or erythrocytes, and we expect that new variants will be identified in the near future. Many of the known genetic variants are quite common. Therefore, it is important to understand better how the enzymes regulating fatty acid metabolism, and the genes coding them, modify the effect of dietary intake of fatty acids on metabolism, low-grade inflammation, and metabolic diseases such as T2D. This understanding may help us to move towards personalized nutrition. It is also noteworthy that ethnicity may have an impact on gene-diet interactions. Most of the studies on interactions between genes and dietary fat in the regulation of fatty acid composition of plasma lipids are observational. Study designs and data collection should be carefully considered in the interpretation of the results. There are only a few intervention trials regarding this topic, and most of them were performed without pre-selected genotypes. Definite answers regarding true gene $\times$ diet interactions may need well-planned intervention studies with specific hypotheses and pre-selected genotypes.

Author Contributions: All authors were involved in the literature research, writing, reviewing, and editing of the manuscript.

Funding: This research was funded by the Academy of Finland (ML), grant number 309311, and Juho Vainio Foundation (US).

Conflicts of Interest: The authors declare no conflict of interest. 


\section{References}

1. Farquhar, J.W.; Ahrens, E.H., Jr. Effects of dietary fats on human erythrocyte fatty acid patterns. J. Clin. Investig. 1963, 42, 675-685. [CrossRef] [PubMed]

2. Hunter, D. Biochemical indicators of dietary fat. In Nutritional Epidemiology; Willett, W., Ed.; Oxford University Press: Oxford, UK, 1990.

3. Vessby, B.; Lithell, H.; Gustafsson, I.B.; Boberg, J. Changes in the fatty acid composition of the plasma lipid esters during lipid-lowering treatment with diet, clofibrate and niceritrol. reduction of the proportion of linoleate by clofibrate but not by niceritrol. Atherosclerosis 1980, 35, 51-65. [CrossRef]

4. Sarkkinen, E.S.; Agren, J.J.; Ahola, I.; Ovaskainen, M.L.; Uusitupa, M.I. Fatty acid composition of serum cholesterol esters, and erythrocyte and platelet membranes as indicators of long-term adherence to fat-modified diets. Am. J. Clin. Nutr. 1994, 59, 364-370. [CrossRef] [PubMed]

5. Carta, G.; Murru, E.; Banni, S.; Manca, C. Palmitic acid: Physiological role, metabolism and nutritional implications. Front. Physiol. 2017, 8, 902. [CrossRef] [PubMed]

6. Weitkunat, K.; Schumann, S.; Nickel, D.; Hornemann, S.; Petzke, K.J.; Schulze, M.B.; Pfeiffer, A.F.; Klaus, S. Odd-Chain Fatty acids as a biomarker for dietary fiber intake: A novel pathway for endogenous production from propionate. Am. J. Clin. Nutr. 2017, 105, 1544-1551. [CrossRef] [PubMed]

7. Saadatian-Elahi, M.; Slimani, N.; Chajes, V.; Jenab, M.; Goudable, J.; Biessy, C.; Ferrari, P.; Byrnes, G.; Autier, P.; Peeters, P.H.; et al. Plasma phospholipid fatty acid profiles and their association with food intakes: Results from a cross-sectional study within the european prospective investigation into cancer and nutrition. Am. J. Clin. Nutr. 2009, 89, 331-346. [CrossRef] [PubMed]

8. Ozogul, Y.; Ozogul, F.; Cicek, E.; Polat, A.; Kuley, E. Fat content and fatty acid compositions of 34 marine water fish species from the mediterranean sea. Int. J. Food Sci. Nutr. 2008, 60, 464-475. [CrossRef] [PubMed]

9. Aggelousis, G.; Lazos, E.S. Fatty acid composition of the lipids from eight freshwater fish species from greece. J. Food Compos. Anal. 1991, 4, 68-76. [CrossRef]

10. Vidgren, H.M.; Agren, J.J.; Schwab, U.; Rissanen, T.; Hanninen, O.; Uusitupa, M.I. Incorporation of n-3 fatty acids into plasma lipid fractions, and erythrocyte membranes and platelets during dietary supplementation with fish, fish oil, and docosahexaenoic acid-rich oil among healthy young men. Lipids 1997, 32, 697-705. [CrossRef] [PubMed]

11. Katan, M.B.; Deslypere, J.P.; van Birgelen, A.P.; Penders, M.; Zegwaard, M. Kinetics of the incorporation of dietary fatty acids into serum cholesteryl esters, erythrocyte membranes, and adipose tissue: An 18-month controlled study. J. Lipid Res. 1997, 38, 2012-2022. [PubMed]

12. Rodriguez, A.; Sarda, P.; Nessmann, C.; Boulot, P.; Leger, C.L.; Descomps, B. Delta6- and delta5-desaturase activities in the human fetal liver: Kinetic aspects. J. Lipid Res. 1998, 39, 1825-1832. [PubMed]

13. Takkunen, M.; Agren, J.; Kuusisto, J.; Laakso, M.; Uusitupa, M.; Schwab, U. Dietary fat in relation to erythrocyte fatty acid composition in men. Lipids 2013, 48, 1093-1102. [CrossRef] [PubMed]

14. Vidgren, H.M.; Louheranta, A.M.; Agren, J.J.; Schwab, U.S.; Uusitupa, M.I. Divergent incorporation of dietary trans fatty acids in different serum lipid fractions. Lipids 1998, 33, 955-962. [CrossRef] [PubMed]

15. Lankinen, M.A.; Stancakova, A.; Uusitupa, M.; Agren, J.; Pihlajamaki, J.; Kuusisto, J.; Schwab, U.; Laakso, M. Plasma fatty acids as predictors of glycaemia and type 2 diabetes. Diabetologia 2015, 58, 2533-2544. [CrossRef] [PubMed]

16. Lopez-Miranda, J.; Williams, C.; Lairon, D. Dietary, physiological, genetic and pathological influences on postprandial lipid metabolism. Br. J. Nutr. 2007, 98, 458-473. [CrossRef] [PubMed]

17. Smith, C.E.; Ordovas, J.M. Fatty acid interactions with genetic polymorphisms for cardiovascular disease. Curr. Opin. Clin. Nutr. Metab. Care 2010, 13, 139-144. [CrossRef] [PubMed]

18. Tanaka, T.; Shen, J.; Abecasis, G.R.; Kisialiou, A.; Ordovas, J.M.; Guralnik, J.M.; Singleton, A.; Bandinelli, S.; Cherubini, A.; Arnett, D.; et al. Genome-wide association study of plasma polyunsaturated fatty acids in the inchianti study. PLoS Genet. 2009, 5, e1000338. [CrossRef] [PubMed]

19. Zhang, J.Y.; Kothapalli, K.S.; Brenna, J.T. Desaturase and elongase-limiting endogenous long-chain polyunsaturated fatty acid biosynthesis. Curr. Opin. Clin. Nutr. Metab. Care 2016, 19, 103-110. [CrossRef] [PubMed] 
20. Agren, J.J.; Valve, R.; Vidgren, H.; Laakso, M.; Uusitupa, M. Postprandial lipemic response is modified by the polymorphism at codon 54 of the fatty acid-binding protein 2 gene. Arterioscler. Thromb. Vasc. Biol. 1998, 18, 1606-1610. [CrossRef] [PubMed]

21. Baier, L.J.; Sacchettini, J.C.; Knowler, W.C.; Eads, J.; Paolisso, G.; Tataranni, P.A.; Mochizuki, H.; Bennett, P.H.; Bogardus, C.; Prochazka, M. An amino acid substitution in the human intestinal fatty acid binding protein is associated with increased fatty acid binding, increased fat oxidation, and insulin resistance. J. Clin. Investig. 1995, 95, 1281-1287. [CrossRef] [PubMed]

22. Yamada, K.; Yuan, X.; Ishiyama, S.; Koyama, K.; Ichikawa, F.; Koyanagi, A.; Koyama, W.; Nonaka, K. Association between Ala54Thr substitution of the fatty acid-binding protein 2 gene with insulin resistance and intra-abdominal fat thickness in japanese men. Diabetologia 1997, 40, 706-710. [CrossRef] [PubMed]

23. Agren, J.J.; Vidgren, H.M.; Valve, R.S.; Laakso, M.; Uusitupa, M.I. Postprandial responses of individual fatty acids in subjects homozygous for the threonine- or alanine-encoding allele in codon 54 of the intestinal fatty acid binding protein 2 gene. Am. J. Clin. Nutr. 2001, 73, 31-35. [CrossRef] [PubMed]

24. Berthier, M.T.; Couillard, C.; Prud'homme, D.; Nadeau, A.; Bergeron, J.; Tremblay, A.; Despres, J.P.; Vohl, M.C. Effects of the FABP2 A54T mutation on triglyceride metabolism of viscerally obese men. Obes. Res. 2001, 9 , 668-675. [CrossRef] [PubMed]

25. Okada, T.; Sato, N.F.; Kuromori, Y.; Miyashita, M.; Iwata, F.; Hara, M.; Harada, K.; Hattori, H. Thr-Encoding allele homozygosity at codon 54 of fabp 2 gene may be associated with impaired delta 6 desatruase activity and reduced plasma arachidonic acid in obese children. J. Atheroscler. Thromb. 2006, 13, 192-196. [CrossRef] [PubMed]

26. Almeida, J.C.; Gross, J.L.; Canani, L.H.; Zelmanovitz, T.; Perassolo, M.S.; Azevedo, M.J. The Ala54Thr polymorphism of the fabp2 gene influences the postprandial fatty acids in patients with type 2 diabetes. J. Clin. Endocrinol. Metab. 2010, 95, 3909-3917. [CrossRef] [PubMed]

27. Sjogren, P.; Sierra-Johnson, J.; Gertow, K.; Rosell, M.; Vessby, B.; de Faire, U.; Hamsten, A.; Hellenius, M.L.; Fisher, R.M. Fatty acid desaturases in human adipose tissue: Relationships between gene expression, desaturation indexes and insulin resistance. Diabetologia 2008, 51, 328-335. [CrossRef] [PubMed]

28. Warensjo, E.; Rosell, M.; Hellenius, M.L.; Vessby, B.; De Faire, U.; Riserus, U. Associations between estimated fatty acid desaturase activities in serum lipids and adipose tissue in humans: Links to obesity and insulin resistance. Lipids Health. Dis. 2009, 8, 37. [CrossRef] [PubMed]

29. Kroger, J.; Schulze, M.B. Recent insights into the relation of delta5 desaturase and delta6 desaturase activity to the development of type 2 diabetes. Curr. Opin. Lipidol. 2012, 23, 4-10. [CrossRef] [PubMed]

30. Mahendran, Y.; Agren, J.; Uusitupa, M.; Cederberg, H.; Vangipurapu, J.; Stancakova, A.; Schwab, U.; Kuusisto, J.; Laakso, M. Association of erythrocyte membrane fatty acids with changes in glycemia and risk of type 2 diabetes. Am. J. Clin. Nutr. 2014, 99, 79-85. [CrossRef] [PubMed]

31. Jacobs, S.; Schiller, K.; Jansen, E.H.; Boeing, H.; Schulze, M.B.; Kroger, J. Evaluation of various biomarkers as potential mediators of the association between delta 5 desaturase, delta 6 desaturase, and stearoyl-coa desaturase activity and incident type 2 diabetes in the european prospective investigation into cancer and nutrition-potsdam study. Am. J. Clin. Nutr. 2015, 102, 155-164. [PubMed]

32. Yary, T.; Voutilainen, S.; Tuomainen, T.P.; Ruusunen, A.; Nurmi, T.; Virtanen, J.K. Serum N-6 polyunsaturated fatty acids, delta5- and delta6-desaturase activities, and risk of incident type 2 diabetes in men: The kuopio ischaemic heart disease risk factor study. Am. J. Clin. Nutr. 2016, 103, 1337-1343. [CrossRef] [PubMed]

33. Takkunen, M.J.; Schwab, U.S.; de Mello, V.D.; Eriksson, J.G.; Lindstrom, J.; Tuomilehto, J.; Uusitupa, M.I.; DPS Study Group. Longitudinal associations of serum fatty acid composition with type 2 diabetes risk and markers of insulin secretion and sensitivity in the finnish diabetes prevention study. Eur. J. Nutr. 2016, 55, 967-979. [CrossRef] [PubMed]

34. Willer, C.J.; Schmidt, E.M.; Sengupta, S.; Peloso, G.M.; Gustafsson, S.; Kanoni, S.; Ganna, A.; Chen, J.; Buchkovich, M.L.; Mora, S.; et al. Discovery and refinement of loci associated with lipid levels. Nat. Genet. 2013, 45, 1274-1283. [CrossRef] [PubMed]

35. Del Gobbo, L.C.; Imamura, F.; Aslibekyan, S.; Marklund, M.; Virtanen, J.K.; Wennberg, M.; Yakoob, M.Y.; Chiuve, S.E.; Dela Cruz, L.; Frazier-Wood, A.C.; et al. Omega-3 polyunsaturated fatty acid biomarkers and coronary heart disease: Pooling project of 19 cohort studies. JAMA Intern. Med. 2016, 176, 1155-1166. [CrossRef] [PubMed] 
36. Vaittinen, M.; Mannisto, V.; Kakela, P.; Agren, J.; Tiainen, M.; Schwab, U.; Pihlajamaki, J. Interorgan cross talk between fatty acid metabolism, tissue inflammation, and fads2 genotype in humans with obesity. Obesity (Silver Spring) 2017, 25, 545-552. [CrossRef] [PubMed]

37. Howard, T.D.; Mathias, R.A.; Seeds, M.C.; Herrington, D.M.; Hixson, J.E.; Shimmin, L.C.; Hawkins, G.A.; Sellers, M.; Ainsworth, H.C.; Sergeant, S.; et al. DNA methylation in an enhancer region of the fads cluster is associated with fads activity in human liver. PLoS ONE 2014, 9, e97510. [CrossRef] [PubMed]

38. Reynolds, L.M.; Howard, T.D.; Ruczinski, I.; Kanchan, K.; Seeds, M.C.; Mathias, R.A.; Chilton, F.H. Tissue-specific impact of fads cluster variants on fads1 and fads2 gene expression. PLoS ONE 2018, 13, e0194610. [CrossRef] [PubMed]

39. Schaeffer, L.; Gohlke, H.; Muller, M.; Heid, I.M.; Palmer, L.J.; Kompauer, I.; Demmelmair, H.; Illig, T.; Koletzko, B.; Heinrich, J. Common genetic variants of the fads1 fads2 gene cluster and their reconstructed haplotypes are associated with the fatty acid composition in phospholipids. Hum. Mol. Genet. 2006, 15, 1745-1756. [CrossRef] [PubMed]

40. Rzehak, P.; Heinrich, J.; Klopp, N.; Schaeffer, L.; Hoff, S.; Wolfram, G.; Illig, T.; Linseisen, J. Evidence for an association between genetic variants of the fatty acid desaturase 1 fatty acid desaturase 2 (FADS1 FADS2) gene cluster and the fatty acid composition of erythrocyte membranes. Br. J. Nutr. 2009, 101, 20-26. [CrossRef] [PubMed]

41. Lemaitre, R.N.; Tanaka, T.; Tang, W.; Manichaikul, A.; Foy, M.; Kabagambe, E.K.; Nettleton, J.A.; King, I.B.; Weng, L.C.; Bhattacharya, S.; et al. Genetic loci associated with plasma phospholipid n-3 fatty acids: A meta-analysis of genome-wide association studies from the CHARGE consortium. PLoS Genet. 2011, 7, e1002193. [CrossRef] [PubMed]

42. Fumagalli, M.; Moltke, I.; Grarup, N.; Racimo, F.; Bjerregaard, P.; Jorgensen, M.E.; Korneliussen, T.S.; Gerbault, P.; Skotte, L.; Linneberg, A.; et al. Greenlandic inuit show genetic signatures of diet and climate adaptation. Science 2015, 349, 1343-1347. [CrossRef] [PubMed]

43. Pihlajamaki, J.; Schwab, U.; Kaminska, D.; Agren, J.; Kuusisto, J.; Kolehmainen, M.; Paananen, J.; Laakso, M.; Uusitupa, M. Dietary polyunsaturated fatty acids and the pro12ala polymorphisms of pparg regulate serum lipids through divergent pathways: A randomized crossover clinical trial. Genes Nutr. 2015, 10. [CrossRef] [PubMed]

44. Zietemann, V.; Kroger, J.; Enzenbach, C.; Jansen, E.; Fritsche, A.; Weikert, C.; Boeing, H.; Schulze, M.B. Genetic variation of the FADS1 FADS2 gene cluster and N-6 PUFA composition in erythrocyte membranes in the european prospective investigation into cancer and nutrition-potsdam study. Br. J. Nutr. 2010, 104, 1748-1759. [CrossRef] [PubMed]

45. Molto-Puigmarti, C.; Plat, J.; Mensink, R.P.; Muller, A.; Jansen, E.; Zeegers, M.P.; Thijs, C. FADS1 FADS2 gene variants modify the association between fish intake and the docosahexaenoic acid proportions in human milk. Am. J. Clin. Nutr. 2010, 91, 1368-1376. [CrossRef] [PubMed]

46. Porenta, S.R.; Ko, Y.A.; Gruber, S.B.; Mukherjee, B.; Baylin, A.; Ren, J.; Djuric, Z. Interaction of fatty acid genotype and diet on changes in colonic fatty acids in a mediterranean diet intervention study. Cancer Prev. Res. (Phila) 2013, 6, 1212-1221. [CrossRef] [PubMed]

47. Roke, K.; Mutch, D.M. The role of FADS1/2 polymorphisms on cardiometabolic markers and fatty acid profiles in young adults consuming fish oil supplements. Nutrients 2014, 6, 2290-2304. [CrossRef] [PubMed]

48. Smith, C.E.; Follis, J.L.; Nettleton, J.A.; Foy, M.; Wu, J.H.; Ma, Y.; Tanaka, T.; Manichakul, A.W.; Wu, H.; $\mathrm{Chu}, \mathrm{A} . \mathrm{Y}$; et al. Dietary fatty acids modulate associations between genetic variants and circulating fatty acids in plasma and erythrocyte membranes: Meta-analysis of nine studies in the charge consortium. Mol. Nutr. Food Res. 2015, 59, 1373-1383. [CrossRef] [PubMed]

49. Gillingham, L.G.; Harding, S.V.; Rideout, T.C.; Yurkova, N.; Cunnane, S.C.; Eck, P.K.; Jones, P.J. Dietary oils and FADS1-FADS2 genetic variants modulate [13C] alpha-linolenic acid metabolism and plasma fatty acid composition. Am. J. Clin. Nutr. 2013, 97, 195-207. [CrossRef] [PubMed]

50. Wu, J.H.; Lemaitre, R.N.; Manichaikul, A.; Guan, W.; Tanaka, T.; Foy, M.; Kabagambe, E.K.; Djousse, L.; Siscovick, D.; Fretts, A.M.; et al. Genome-wide association study identifies novel loci associated with concentrations of four plasma phospholipid fatty acids in the de novo lipogenesis pathway: Results from the cohorts for heart and aging research in genomic epidemiology (CHARGE) consortium. Circ. Cardiovasc. Genet. 2013, 6, 171-183. [CrossRef] [PubMed] 
51. Guan, W.; Steffen, B.T.; Lemaitre, R.N.; Wu, J.H.; Tanaka, T.; Manichaikul, A.; Foy, M.; Rich, S.S.; Wang, L.; Nettleton, J.A.; et al. Genome-wide association study of plasma n6 polyunsaturated fatty acids within the cohorts for heart and aging research in genomic epidemiology consortium. Circ. Cardiovasc. Genet. 2014, 7, 321-331. [CrossRef] [PubMed]

52. Dorajoo, R.; Sun, Y.; Han, Y.; Ke, T.; Burger, A.; Chang, X.; Low, H.Q.; Guan, W.; Lemaitre, R.N.; Khor, C.C.; et al. A genome-wide association study of $n-3$ and n-6 plasma fatty acids in a singaporean chinese population. Genes Nutr. 2015, 10. [CrossRef] [PubMed]

53. Lemaitre, R.N.; King, I.B.; Kabagambe, E.K.; Wu, J.H.; McKnight, B.; Manichaikul, A.; Guan, W.; Sun, Q.; Chasman, D.I.; Foy, M.; et al. Genetic loci associated with circulating levels of very long-chain saturated fatty acids. J. Lipid Res. 2015, 56, 176-184. [CrossRef] [PubMed]

54. Mozaffarian, D.; Kabagambe, E.K.; Johnson, C.O.; Lemaitre, R.N.; Manichaikul, A.; Sun, Q.; Foy, M.; Wang, L.; Wiener, H.; Irvin, M.R.; et al. Genetic loci associated with circulating phospholipid trans fatty acids: A meta-analysis of genome-wide association studies from the CHARGE consortium. Am. J. Clin. Nutr. 2015, 101, 398-406. [CrossRef] [PubMed]

55. Tintle, N.L.; Pottala, J.V.; Lacey, S.; Ramachandran, V.; Westra, J.; Rogers, A.; Clark, J.; Olthoff, B.; Larson, M.; Harris, W.; et al. A genome-wide association study of saturated, mono- and polyunsaturated red blood cell fatty acids in the framingham heart offspring study. prostaglandins leukot. essent. Fatty Acids 2015, 94, 65-72. [CrossRef] [PubMed]

56. de Oliveira Otto, M.C.; Lemaitre, R.N.; Sun, Q.; King, I.B.; Wu, J.H.Y.; Manichaikul, A.; Rich, S.S.; Tsai, M.Y.; Chen, Y.D.; Fornage, M.; et al. Genome-wide association meta-analysis of circulating odd-numbered chain saturated fatty acids: Results from the CHARGE consortium. PLoS ONE 2018, 13, e0196951. [CrossRef] [PubMed]

57. Xie, L.; Innis, S.M. Genetic variants of the FADS1 FADS2 gene cluster are ASSOCIATED with altered (N-6) and (N-3) essential fatty acids in plasma and erythrocyte phospholipids in women during pregnancy and in breast milk during lactation. J. Nutr. 2008, 138, 2222-2228. [CrossRef] [PubMed]

58. Dumont, J.; Huybrechts, I.; Spinneker, A.; Gottrand, F.; Grammatikaki, E.; Bevilacqua, N.; Vyncke, K.; Widhalm, K.; Kafatos, A.; Molnar, D.; et al. FADS1 genetic variability interacts with dietary alpha-linolenic acid intake to affect serum Non-HDL-Cholesterol concentrations in european adolescents. J. Nutr. 2011, 141, 1247-1253. [CrossRef] [PubMed]

59. Merino, D.M.; Johnston, H.; Clarke, S.; Roke, K.; Nielsen, D.; Badawi, A.; El-Sohemy, A.; Ma, D.W.; Mutch, D.M. Polymorphisms in FADS1 and FADS2 alter desaturase activity in young caucasian and asian adults. Mol. Genet. Metab. 2011, 103, 171-178. [CrossRef] [PubMed]

60. Hong, S.H.; Kwak, J.H.; Paik, J.K.; Chae, J.S.; Lee, J.H. Association of polymorphisms in FADS gene with age-related changes in serum phospholipid polyunsaturated fatty acids and oxidative stress markers in middle-aged nonobese men. Clin. Interv. Aging 2013, 8, 585-596. [PubMed]

61. Roke, K.; Ralston, J.C.; Abdelmagid, S.; Nielsen, D.E.; Badawi, A.; El-Sohemy, A.; Ma, D.W.; Mutch, D.M. Variation in the FADS1/2 gene cluster alters plasma n-6 PUFA and is weakly associated with hsCRP levels in healthy young adults. Prostaglandins Leukot. Essent. Fatty Acids 2013, 89, 257-263. [CrossRef] [PubMed]

62. Huang, T.; Sun, J.; Chen, Y.; Xie, H.; Xu, D.; Huang, J.; Li, D. Genetic variants in desaturase gene, erythrocyte fatty acids, and risk for type 2 diabetes in chinese hans. Nutrition 2014, 30, 897-902. [CrossRef] [PubMed]

63. Andersen, M.K.; Jorsboe, E.; Sandholt, C.H.; Grarup, N.; Jorgensen, M.E.; Faergeman, N.J.; Bjerregaard, P.; Pedersen, O.; Moltke, I.; Hansen, T.; et al. Identification of novel genetic determinants of erythrocyte membrane fatty acid composition among greenlanders. PLoS Genet. 2016, 12, e1006119. [CrossRef] [PubMed]

64. Takkunen, M.J.; de Mello, V.D.; Schwab, U.S.; Kuusisto, J.; Vaittinen, M.; Agren, J.J.; Laakso, M.; Pihlajamaki, J.; Uusitupa, M.I. Gene-diet interaction of a common fads1 variant with marine polyunsaturated fatty acids for fatty acid composition in plasma and erythrocytes among men. Mol. Nutr. Food Res. 2016, 60, 381-389. [CrossRef] [PubMed]

65. de la Garza Puentes, A.; Montes Goyanes, R.; Chisaguano Tonato, A.M.; Torres-Espinola, F.J.; Arias Garcia, M.; de Almeida, L.; Bonilla Aguirre, M.; Guerendiain, M.; Castellote Bargallo, A.I.; Segura Moreno, M.; et al. Association of maternal weight with fads and elovl genetic variants and fatty acid levels- the PREOBE follow-up. PLoS ONE 2017, 12, e0179135. [CrossRef] [PubMed] 
66. Guo, H.; Zhang, L.; Zhu, C.; Yang, F.; Wang, S.; Zhu, S.; Ma, X. A single nucleotide polymorphism in the FADS1 gene is associated with plasma fatty acid and lipid profiles and might explain gender difference in body fat distribution. Lipids Health. Dis. 2017, 16. [CrossRef]

67. Kim, M.; Kim, M.; Yoo, H.J.; Lee, A.; Jeong, S.; Lee, J.H. Associations among FADS1 rs174547, eicosapentaenoic acid/arachidonic acid ratio, and arterial stiffness in overweight subjects. Prostaglandins Leukot. Essent. Fatty Acids 2018, 130, 11-18. [CrossRef] [PubMed]

68. Li, P.; Zhao, J.; Kothapalli, K.S.D.; Li, X.; Li, H.; Han, Y.; Mi, S.; Zhao, W.; Li, Q.; Zhang, H.; et al. A regulatory insertion-deletion polymorphism in the fads gene cluster influences PUFA and lipid profiles among chinese adults: A population-based study. Am. J. Clin. Nutr. 2018, 107, 867-875. [CrossRef] [PubMed]

69. Al-Hilal, M.; Alsaleh, A.; Maniou, Z.; Lewis, F.J.; Hall, W.L.; Sanders, T.A.; O’Dell, S.D.; MARINA study team. Genetic variation at the FADS1-FADS2 gene locus influences delta-5 desaturase activity and LC-PUFA proportions after fish oil supplement. J. Lipid Res. 2013, 54, 542-551. [CrossRef] [PubMed]

70. Scholtz, S.A.; Kerling, E.H.; Shaddy, D.J.; Li, S.; Thodosoff, J.M.; Colombo, J.; Carlson, S.E. Docosahexaenoic acid (DHA) supplementation in pregnancy differentially modulates arachidonic acid and DHA status across FADS genotypes in pregnancy. Prostaglandins Leukot. Essent. Fatty Acids 2015, 94, 29-33. [CrossRef] [PubMed]

71. Wang, L.; Athinarayanan, S.; Jiang, G.; Chalasani, N.; Zhang, M.; Liu, W. Fatty acid desaturase 1 gene polymorphisms control human hepatic lipid composition. Hepatology 2015, 61, 119-128. [CrossRef] [PubMed]

(C) 2018 by the authors. Licensee MDPI, Basel, Switzerland. This article is an open access article distributed under the terms and conditions of the Creative Commons Attribution (CC BY) license (http:/ / creativecommons.org/licenses/by/4.0/). 